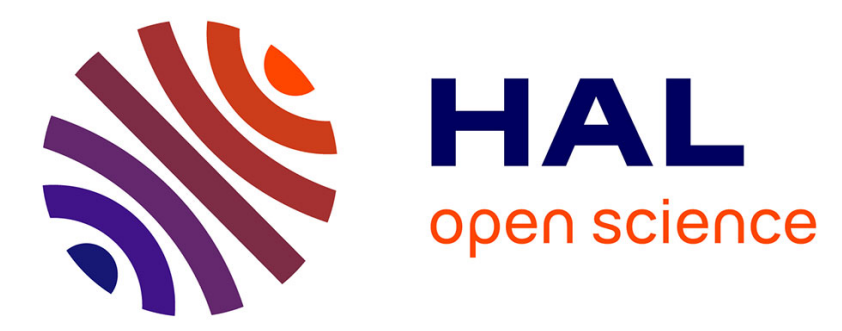

\title{
Thin Films of Fully Noble Metal-Free POM@MOF for Photocatalytic Water Oxidation
}

Grégoire Paille, Maria Gomez-Mingot, Catherine Roch-Marchal, Mohamed Haouas, Youven Benseghir, Thomas Pino, Minh-Huong Ha-Thi, Gautier Landrot, Pierre Mialane, Marc Fontecave, et al.

\section{To cite this version:}

Grégoire Paille, Maria Gomez-Mingot, Catherine Roch-Marchal, Mohamed Haouas, Youven Benseghir, et al.. Thin Films of Fully Noble Metal-Free POM@MOF for Photocatalytic Water Oxidation. ACS Applied Materials \& Interfaces, 2019, 11 (51), pp.47837 - 47845. 10.1021/acsami.9b13121 . hal03094589

\section{HAL Id: hal-03094589 \\ https://hal.science/hal-03094589}

Submitted on 4 Jan 2021

HAL is a multi-disciplinary open access archive for the deposit and dissemination of scientific research documents, whether they are published or not. The documents may come from teaching and research institutions in France or abroad, or from public or private research centers.
L'archive ouverte pluridisciplinaire HAL, est destinée au dépôt et à la diffusion de documents scientifiques de niveau recherche, publiés ou non, émanant des établissements d'enseignement et de recherche français ou étrangers, des laboratoires publics ou privés. 


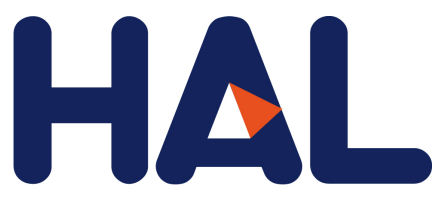

archives-ouvertes

\title{
Thin Films of Fully Noble Metal-Free POM@MOF for Photo- catalytic Water Oxidation
}

\author{
Grégoire Paille, Maria Gomez-Mingot, Catherine Roch-Marchal, Mohamed \\ Haouas, Youven Ben-Seghir, Thomas Pino, Minh-Huong Ha-Thi, Gautier \\ Landrot, Pierre Mialane, Marc Fontecave, et al.
}

\section{To cite this version:}

Grégoire Paille, Maria Gomez-Mingot, Catherine Roch-Marchal, Mohamed Haouas, Youven BenSeghir, et al.. Thin Films of Fully Noble Metal-Free POM@MOF for Photo- catalytic Water Oxidation. ACS Applied Materials \& Interfaces, Washington, D.C.: American Chemical Society, 2019, 11 (51), pp.47837-47845. 10.1021/acsami.9b13121 . hal-02451033

\section{HAL Id: hal-02451033 https://hal.sorbonne-universite.fr/hal-02451033}

Submitted on 23 Jan 2020

HAL is a multi-disciplinary open access archive for the deposit and dissemination of scientific research documents, whether they are published or not. The documents may come from teaching and research institutions in France or abroad, or from public or private research centers.
L'archive ouverte pluridisciplinaire HAL, est destinée au dépôt et à la diffusion de documents scientifiques de niveau recherche, publiés ou non, émanant des établissements d'enseignement et de recherche français ou étrangers, des laboratoires publics ou privés. 


\title{
Thin Films of Fully Noble Metal-Free POM@MOF for Photo- catalytic Water Oxidation
}

\author{
Grégoire Paille, ${ }^{\dagger *}$ Maria Gomez-Mingot, ${ }^{*}$ Catherine Roch-Marchal, ${ }^{\dagger}$ Mohamed Haouas, ${ }^{\dagger}$ Youven Ben- \\ seghir, ${ }^{\dagger+}$ Thomas Pino,\| Minh-Huong Ha-Thi, $\|$ Gautier Landrot,${ }^{\S}$ Pierre Mialane, ${ }^{\dagger}$ Marc Fontecave, ${ }^{\ddagger}$ \\ Anne Dolbecq ${ }^{* \dagger}$ and Caroline Mellot-Draznieks ${ }^{* \dagger}$
}

$\dagger$ Institut Lavoisier de Versailles, UMR CNRS 8180, Université de Versailles Saint-Quentin en Yvelines, Université ParisSaclay, 45 Avenue des Etats-Unis, Versailles 78035 Cedex, France

\$Laboratoire de Chimie des Processus Biologiques, Collège de France, Sorbonne Université, CNRS UMR 8229, PSL Research University, 11 Place Marcelin Berthelot, Paris 75231 Cedex 05, France

\|Institut des Sciences Moléculaires d'Orsay, CNRS, Université Paris-Sud, Université Paris-Saclay, F-91405 Orsay, France

§Synchrotron Soleil, l’Orme des Merisiers, Saint-Aubin 91192 Cedex, France

KEYWORDS: water splitting, thin films, metal-organic frameworks, polyoxometalates, artificial photosynthesis, ITO electrodes

\begin{abstract}
P}_{2} \mathrm{~W}_{18} \mathrm{Co}_{4} @ \mathrm{MOF}-545$ which contains the sandwich-type polyoxometalate $\left(\mathrm{POM}{ }^{2}\left(\mathrm{PW}_{9} \mathrm{O}_{34}\right)_{2} \mathrm{Co}_{4}\left(\mathrm{H}_{2} \mathrm{O}\right)_{2}\right]^{10-}$ $\left(\mathrm{P}_{2} \mathrm{~W}_{18} \mathrm{Co}_{4}\right)$ immobilized in the porphyrinic MOF-545 framework, is a "three-in-one" (porosity + light capture + catalysis) heterogeneous photosystem for the oxygen evolution reaction (OER). Thin films of this composite were synthesized on transparent and conductive indium tin oxide (ITO) supports using electrophoretic (EP) or drop casting (DC) methods, thus providing easy-to-use devices. Their electro- and photocatalytic activities for OER were investigated. Remarkably, both types of films exhibit higher turnover numbers (TONs) than the original bulk material previously studied as suspension for the photocatalytic OER, with TONs after 2 hours equal to 1600 and 403 for DC and EP films respectively compared to 70 for the suspension. This difference of catalytic activities is related to the proportion of efficiently illuminated crystallites, whereby a DC thin film offers the largest proportion of POM@MOF crystallites exposed to light due to its lower thickness when compared to an EP film or crystals in suspension. Such devices can be easily recycled by simply removing them from the reaction medium and washing them before reuse. The films were fully characterized with EXAFS and XANES spectroscopies, Raman, Scanning Electron Microscopy and electrochemistry, before and after catalysis. The combination of all these techniques shows the stability of both the POM and the MOF within the composite upon water oxidation reaction.
\end{abstract}

\section{INTRODUCTION}

Metal-organic frameworks (MOF) have attracted immense research interest in the design of heterogeneous catalysts ${ }^{1-3}$ with promising potential both in electro- and photocatalysis. ${ }^{4-10}$ Their outstanding features, combining their crystalline structure, tunable porosity and high specific surface areas with the versatile functionalization of their organic linker, make them a unique platform to target new functional materials. Owing to the strong incentive to develop sustainable and clean energy sources in the context of fossil fuels shortage and environmental pollution, water splitting into $\mathrm{O}_{2}$ and $\mathrm{H}_{2}$ through the photo(electro)chemical oxygen evolution and the hydrogen evolution reactions, OER and HER, respectively, still requires new, efficient and cheap, catalytic materials. In that respect, recent research efforts have aimed at functionalizing MOFs towards OER and HER. ${ }^{11-14}$

While significant advances have been done on the use of MOFs for HER, much fewer studies have been carried out towards OER, probably as a result of their frequent lack of stability under water oxidation reaction conditions. ${ }^{15}$ The emergence of MOF-based solids for OER has been particularly driven by the motivation to handle catalysts containing earth-abundant elements rather than costly noble metals. Various strategies have been proposed to design MOF-based mate- rials for electro- or photocatalytic OER. An early case was provided in electrocatalysis with the chemically robust cobaltimidazolate, ZIF-9, where the Co nodes are the catalytically active single-sites. ${ }^{16,17}$ Another efficient strategy consists in immobilizing an OER catalyst into the pores of a MOF host, as exemplified with cobalt-based polyoxometalates (POMs) encapsulated in ZIF-8, ${ }^{18}$ MIL-101 19 or MIL-101. ${ }^{20}$ Other recent heterogeneous MOF-based electrocatalysts for OER include porphyrin-based MOFs, such as the free base porphyrin $\mathrm{Pb}$ $\mathrm{MOF}^{21}$ or the PCN-224-Ni containing nickel porphyrin linker. $^{22,23}$ While above recent developments opened new avenues for using MOF materials for electrocatalytic OER purposes, their use for photocatalytic OER is currently more limited. ${ }^{24-29}$ A pioneer strategy for designing photocatalytically active MOFs was reported by Lin et al. whereby the zirconium-based UiO-67, namely $\mathrm{Zr}_{6} \mathrm{O}_{4}(\mathrm{OH})_{4}(\text { bpdc })_{6}$ (bpdc = biphenyl dicarboxylate) is used as a modular scaffold to perform OER. In this case, the MOF is functionalized with Ir-based bipyridine linkers capable of locally performing OER, whilst the rest of the MOF scaffold stays catalytically inactive. ${ }^{29}$

Since then, the use of MOFs as photosensitizers to yield lightharvesting frameworks has attracted ever-growing research 


\section{a) porphyrin}

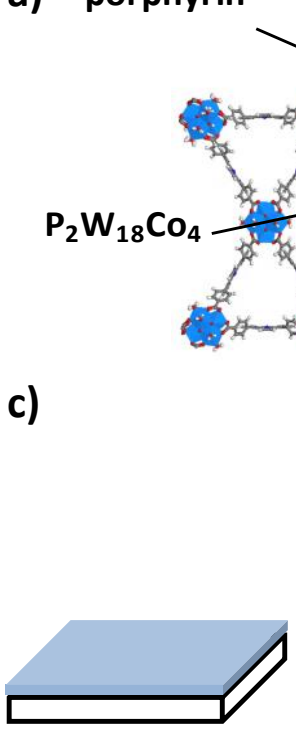

ITO support

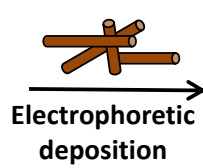

deposition

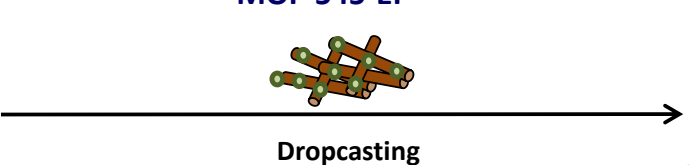

MOF-545-EP

$\overrightarrow{\text { Impregnation }}$ Water, RT, $6 \mathrm{~h}$

Dropcasting b)
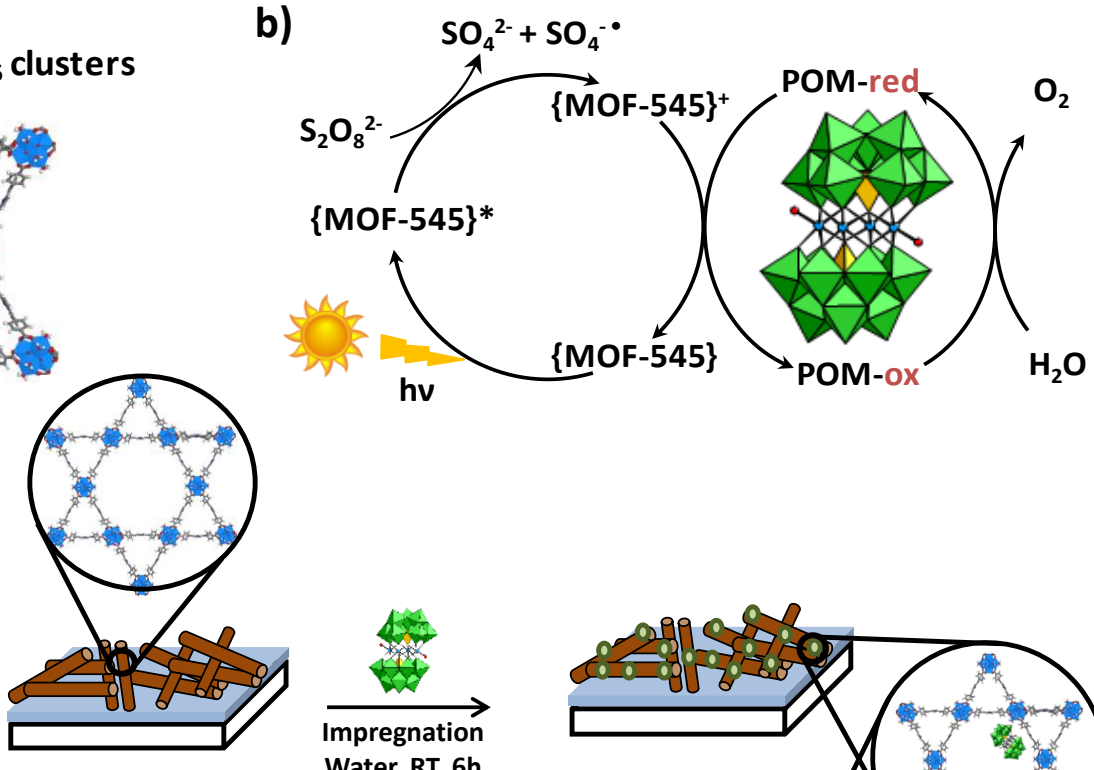

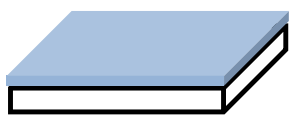

\section{$\mathrm{P}_{2} \mathrm{~W}_{18} \mathrm{Co}_{4} @ M O F-545-D C$}

Figure 1. $\mathrm{P}_{2} \mathrm{~W}_{18} \mathrm{Co}_{4} @$ MOF-545 photosystem for OER. (a) Schematic representation of the $\mathbf{P}_{\mathbf{2}} \mathbf{W}_{\mathbf{1 8}} \mathbf{C o}_{\mathbf{4}} @ \mathbf{M O F}-\mathbf{5 4 5}$ composite with its three components (porous channel, POM catalyst, porphyrinic photosensitizer). (b) Proposed mechanism for light-driven OER. Reprinted in part with permission from reference 38. Copyright 2019 American Chemical Society. (c) Scheme for $\mathbf{P}_{\mathbf{2}} \mathbf{W}_{\mathbf{1 8}} \mathbf{C o}_{\mathbf{4}} @ \mathbf{M O F}-\mathbf{5 4 5}-\mathbf{D C}$ and $\mathbf{P}_{2} \mathrm{~W}_{18} \mathrm{Co}_{4} @$ MOF-545-EP thin films synthesis.

efforts, ${ }^{30-34}$ making porphyrin-based MOFs an interesting subclass of solids for designing new biomimetic photosystems. ${ }^{35}$ However, the use of such MOFs in photocatalytic applications has been mostly reported for the reduction of $\mathrm{CO}_{2}{ }^{36}$ with only scarce reports for visible light-driven photocatalytic OER so far. ${ }^{37,38} \mathrm{We}$ recently reported the photosensitization of the $\left[\left(\mathrm{PW}_{9} \mathrm{O}_{34}\right)_{2} \mathrm{Co}_{4}\left(\mathrm{H}_{2} \mathrm{O}\right)_{2}\right]^{10-}\left(\mathrm{P}_{2} \mathrm{~W}_{18} \mathrm{Co}_{4}\right)$ POM catalyst by the porphyrins of the MOF-545, within the $\mathrm{P}_{2} \mathrm{~W}_{18} \mathrm{Co}_{4} @ \mathrm{MOF}-545$ solid, ${ }^{38}$ which occurs under visible light irradiation. This provided a rare example of an "all-in-one" (porosity + light capture + catalysis) fully noble metal-free heterogeneous photocatalyst for OER (Figures $1 \mathrm{a}$ and $1 \mathrm{~b}$ ). The unique activity of the $\mathrm{P}_{2} \mathrm{~W}_{18} \mathrm{Co}_{4} @$ MOF-545 photosystem was shown to benefit from key factors, such as the immobilization of the porphyrin as a ligand within the MOF's scaffold, whereby the MOF plays the role of a solid-state photosensitizer. The porosity of the MOF allows facile diffusion of reactants and products. Finally, the confinement of catalytic POMs inside the MOF's pores allows their stabilization while the POM-MOF interface provides key components $(\mathrm{OH}$, labile water molecules) relevant to the OER mechanism. Still, the re-use of such photosystems as powders in suspension requires centrifugations with potential loss of materials.

Further strategies to develop thin films of such catalytically active MOFs are required in the perspective of novel forms of devices and technologies. They currently attract a great deal of attention in sub-fields ranging from optoelectronic devices, sensors to photoand electrocatalysis. ${ }^{39,40}$ As MOFs are mostly obtained as powders, there is a strong incentive to deposit them on transparent conducting supports such as fluorine-doped tin oxide (FTO) or indium tin oxide (ITO) and to formulate them so that not only electronic transport can be improved but also easy-to-use and recyclable setups can be developed. Two kinds of strategies include in situ approaches, whereby the MOF is synthesized in the presence of the support (solvothermal synthesis, layer-by-layer or liquid-phase epitaxy growth, electrodeposition), and ex situ approaches, whereby a pre-synthesized MOF is deposited on the support (spin coating, drop casting, electrophoretic deposition). ${ }^{41,42}$

The development of MOF-based thin films for OER is a recent developing subfield. An early example is that of Zhao et al. whereby nickel-cobalt MOF sheets with coordinatively unsaturated metal sites were shown to function as robust and highly active OER electrocatalysts. ${ }^{43}$ Also the porphyrinic PCN-224-Ni was deposited on ITO by a solvothermal reaction and electrochemically investigated for OER in aqueous solution. ${ }^{22}$ While thin films of porphyrinic MOFs have been the subject of very intense research efforts, ${ }^{44-52}$ reports of porphyrinic-MOF thin films for photocatalytic OER are rather scarce. ${ }^{24-28}$ Here we thus considered investigating the thin film deposition of our recently published $\mathrm{P}_{2} \mathrm{~W}_{18} \mathrm{Co}_{4} @ \mathrm{MOF}-545$ composite ${ }^{38}$ using drop casting and electrophoretic deposition methods on ITO and evaluating its potential for photocatalytic OER. At this stage, ex situ deposition methods were preferred to in situ ones as they were easier to implement for ourPOM@MOF system. We discuss the two thin film deposition methods and characterize the films for their electrochemical properties. Finally, we show that they behave as excellent photocatalysts for OER. The use of thin films is shown to be particularly advantageous, allowing easy re-use and characterizations. 
a)

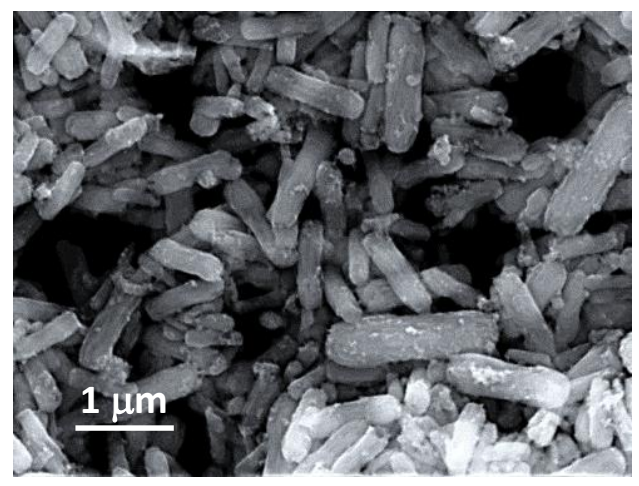

c)

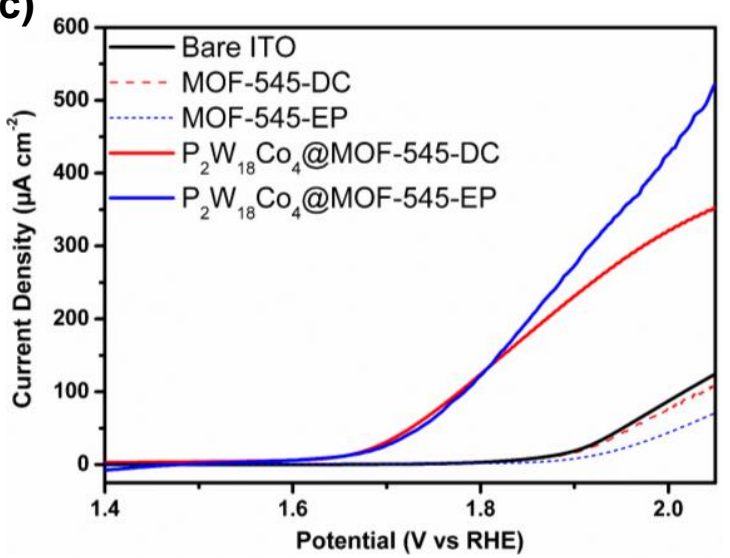

b)

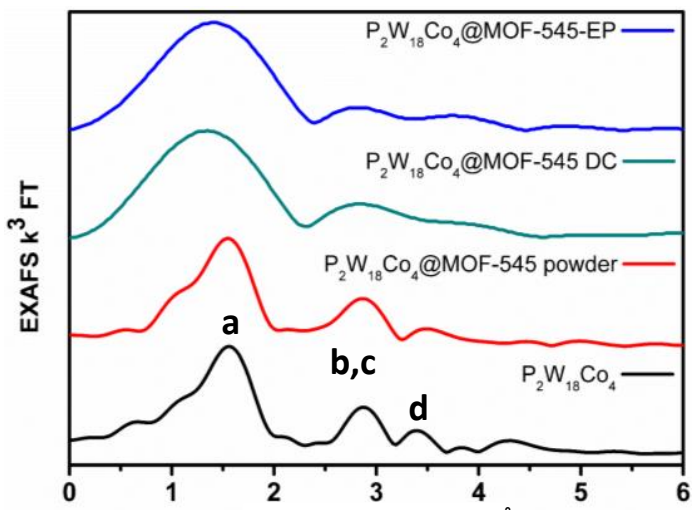

d)

Radial distance, $\mathbf{R}+\Delta \mathbf{R}(\mathbf{A})$

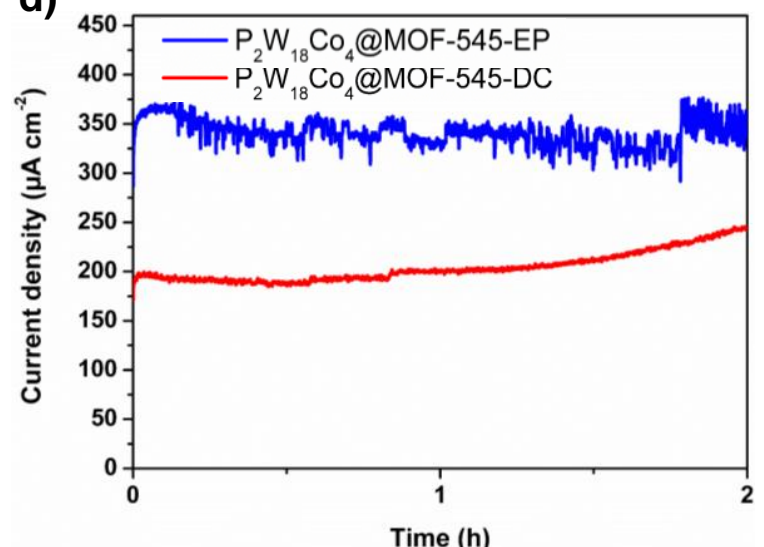

Figure 2. Characterization of POM@MOF thin films. (a) SEM images of $\mathbf{P}_{\mathbf{2}} \mathbf{W}_{\mathbf{1 8}} \mathbf{C o}_{\mathbf{4}} @ \mathbf{M O F - 5 4 5 - E P}$. (b) Comparison of FT-EXAFS

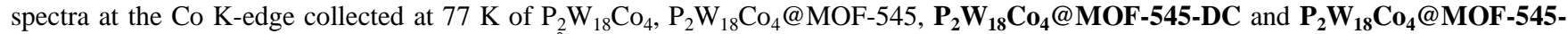
EP. Note that distances are reduced by 0.3-0.4 $\mathrm{A}$ relative to the real distance. Characteristic peaks are indexed to reference in Figure S5. (c) LSV of bare ITO, MOF-545-EP, MOF-545-DC, $\mathbf{P}_{\mathbf{2}} \mathbf{W}_{\mathbf{1 8}} \mathbf{C o}_{\mathbf{4}} @$ MOF-545-DC and $\mathbf{P}_{\mathbf{2}} \mathbf{W}_{\mathbf{1 8}} \mathbf{C o}_{\mathbf{4}} @$ MOF-545-EP in $80 \mathrm{mM} \mathrm{B}(\mathrm{OH})_{3}$ buffer at $\mathrm{pH} 8$ at a scan rate of $5 \mathrm{mV} \mathrm{s}^{-1}$. (d) Current density $v s$. time during CPE at $1.88 \mathrm{~V} v s$. RHE in $80 \mathrm{mM} \mathrm{B}(\mathrm{OH})_{3} \mathrm{pH} 8 \mathrm{buffer}$ for $\mathrm{P}_{2} \mathrm{~W}_{18} \mathrm{Co}_{4} @ \mathrm{MOF}-545-\mathrm{EP}$ and -DC.

\section{RESULTS AND DISCUSSION}

Microcrystalline MOF-545 and $\mathrm{P}_{2} \mathrm{~W}_{18} \mathrm{Co}_{4} @ \mathrm{MOF}-545$ particles were synthesized via a solvothermal route according to a previously reported procedure (See Experimental Section). ${ }^{38}$ Commercially available ITO-coated PET (polyethylene terephthalate) films were preferred to FTO-coated glass in order to facilitate further characterizations using X-ray spectroscopy. As illustrated in Figure 1c, thin films of $\mathrm{P}_{2} \mathrm{~W}_{18} \mathrm{Co}_{4} @ \mathrm{MOF}-545$ on ITO electrodes were prepared either in one-step by drop casting $\mathrm{P}_{2} \mathrm{~W}_{18} \mathrm{Co}_{4} @$ MOF-545 directly on ITO $\left(\mathbf{P}_{2} \mathbf{W}_{18} \mathbf{C o}_{4} @\right.$ MOF-545DC) or using an electrophoretic deposition of the MOF (MOF545-EP) followed by the impregnation with the POM $\left(\mathbf{P}_{2} \mathbf{W}_{18} \mathbf{C o}_{4} @\right.$ MOF-545-EP). For reference purposes (vide infra), MOF-545-DC was also prepared. In the case of electrophoretic deposition, MOF-545-EP films were obtained by dipping two face-to-face ITO electrodes into a toluene suspension of microcrystalline MOF-545 powder. Due to free carboxylate ligands at the MOF surface, particles bear a negatively charged surface. Applying a $45 \mathrm{~V}$ cell voltage between electrodes thus allowed the migration of MOF particles to the anode. The formed MOF-545EP thin films were subsequently impregnated with an aqueous solution of the $\mathrm{P}_{2} \mathrm{~W}_{18} \mathrm{Co}_{4}$-POM to form the desired $\mathbf{P}_{2} \mathbf{W}_{18} \mathbf{C o}_{4} @ M O F-545-E P$ (see Experimental Section). SEM images (Figures 2a and S1) of MOF-545-EP, $\mathbf{P}_{2} \mathbf{W}_{18} \mathrm{Co}_{4} @$ MOF545-EP and $\mathbf{P}_{2} \mathbf{W}_{18} \mathrm{Co}_{\mathbf{4}} @$ MOF-545-DC show that both types of films consist of rod-shape particles (1- $2 \mu \mathrm{m}$ length) characteristic of the six-fold symmetry of the structure. It is apparent that EP allows the formation of denser $(\sim 20 \mu \mathrm{m}$ thickness measured by profilometry) and more homogeneous films than the DC method for which MOF particles are more sparsely distributed on the ITO surface. Powder X-Ray Diffraction (PXRD) patterns collected on bulk $\mathrm{P}_{2} \mathrm{~W}_{18} \mathrm{Co}_{4} @$ MOF-545 and $\mathbf{P}_{2} \mathbf{W}_{18} \mathbf{C o}_{4} @$ MOF-545-EP (Figure $\mathrm{S} 2$ ) confirm the good crystallinity with no additional peak found although, due to the limited thickness of $\mathbf{P}_{2} \mathbf{W}_{18} \mathbf{C o}_{4} @$ MOF-545-EP films, higher-angle peaks were enlarged and had smaller intensities, consistent with PXRD reported on thin films. ${ }^{53,54}$

Before deposition on ITO, the integrity of the POM component within the POM@MOF composite was checked on the bulk using NMR techniques. Liquid-state ${ }^{31} \mathrm{P}$ NMR spectrum (Figure S3) of digested $\mathrm{P}_{2} \mathrm{~W}_{18} \mathrm{Co}_{4} @ \mathrm{MOF}-545$ in a borate buffer at $\mathrm{pH} 10$ showed a single thin peak at $\sim 1828 \mathrm{ppm}$, characteristic of $\mathrm{P}_{2} \mathrm{~W}_{18} \mathrm{Co}_{4},{ }^{55}$ in agreement with those obtained from a solution of $\mathrm{P}_{2} \mathrm{~W}_{18} \mathrm{Co}_{4}$ in a borate buffer at $\mathrm{pH} 8$ and 10 . Solid-state Magic Angle Spinning ${ }^{31} \mathrm{P}$ NMR (MAS-NMR) conducted on bulk $\mathrm{P}_{2} \mathrm{~W}_{18} \mathrm{Co}_{4} @$ MOF-545 showed an enlarged peak at $~ 1700 \mathrm{ppm}$, consistent with previous measurements, while the absence of peak at around 0-10 ppm confirmed the absence of free phosphates and Co-free POMs. In addition, X-Ray spectroscopy at the Co Kedge energy revealed no significant difference between $\mathrm{P}_{2} \mathrm{~W}_{18} \mathrm{Co}_{4}$ or $\mathrm{P}_{2} \mathrm{~W}_{18} \mathrm{Co}_{4} @ \mathrm{MOF}-545$ bulk powders and $\mathbf{P}_{\mathbf{2}} \mathbf{W}_{\mathbf{1 8}} \mathbf{C o}_{4} @ \mathbf{M O F}$ 545-DC and $\mathbf{P}_{2} \mathbf{W}_{18} \mathrm{Co}_{4} @$ MOF-545-EP (Figures $2 b$ and S4).

In agreement with the literature, ${ }^{56}$ prevalent Fourier-transformed (FT) peaks of the $\mathrm{P}_{2} \mathrm{~W}_{18} \mathrm{Co}_{4} \mathrm{POM}$ and $\mathrm{P}_{2} \mathrm{~W}_{18} \mathrm{Co}_{4} @ \mathrm{MOF}-545$ bulk powders were assigned to Co-O (1.6 ̊), Co-P and Co-Co $(2.9 \AA)$ and Co-W (3.4 ̊) atom pairs (Figure S5, Table S1). FT EXAFS 
data on thin films are broader and less-defined than on bulk powder, due to the small amount of material exposed to the beam combined with the relatively low concentration of cobalt atoms in the $\mathrm{P}_{2} \mathrm{~W}_{18} \mathrm{Co}_{4} @ \mathrm{MOF}-545$ composite. Still, the main peak at $1.5 \AA$ characteristic of the first coordination sphere $(\mathrm{Co}-\mathrm{O})$ is close to that observed for the bulk material and the XANES spectra differ from the one obtained for diverse cobalt oxides (Figure S6), providing evidence of the POM's integrity immobilized in MOF545.

The impregnation of $\mathrm{P}_{2} \mathrm{~W}_{18} \mathrm{Co}_{4}$ in MOF-545-EP thin films was performed in identical conditions than those for preparing the $\mathrm{P}_{2} \mathrm{~W}_{18} \mathrm{Co}_{4} @ \mathrm{MOF}-545$ bulk powder further deposited on DC thin films, for which we determined the following formula, $\left[\mathrm{Zr}_{6} \mathrm{O}_{16} \mathrm{H}_{18}\right]_{3}\left[\mathrm{C}_{48} \mathrm{H}_{26} \mathrm{~N}_{4} \mathrm{O}_{8}\right]_{6} \cdot\left[\mathrm{P}_{2} \mathrm{~W}_{18} \mathrm{O}_{70} \mathrm{Co}_{4} \mathrm{H}_{4}\right]_{0.6} \cdot 78 \mathrm{H}_{2} \mathrm{O},{ }^{38}$ leading to surface densities of $16 \mathrm{nmol} \mathrm{cm}$ and $1.5 \mathrm{nmol} \mathrm{cm} \mathrm{cm}^{-2}$ on $\mathbf{P}_{2} W_{18} \mathrm{Co}_{4} @ M O F-545-E P$ and $\quad \mathbf{P}_{2} W_{18} \mathrm{Co}_{4} @ M O F-545-D C$, respectively (see experimental section).

The electrochemical behavior of $\mathrm{P}_{2} \mathrm{~W}_{18} \mathrm{Co}_{4}, \mathbf{P}_{2} \mathbf{W}_{18} \mathbf{C o}_{4} @$ MOF545-EP and $\mathbf{P}_{\mathbf{2}} \mathbf{W}_{18} \mathbf{C o}_{\mathbf{4}} @$ MOF-545-DC was studied. Cyclic voltammograms (CVs) as well as Linear Sweep Voltammetry measurements (LSVs) were conducted in a $80 \mathrm{mM}$ borate buffer at $\mathrm{pH} 8$, at which both the MOF and POM components are stable. $\mathrm{CV}$ s were measured between 0.65 and $1.85 \mathrm{~V} v s$. RHE. The CVs displayed a characteristic wave assigned to $\mathrm{Co}^{\mathrm{II}} / \mathrm{Co}^{\mathrm{III}}$ redox processes of the Co centers of the POM (Figure S7). Half-wave potential is similar for both the POM in solution over a bare ITO electrode and the thin films, measured at $1.35 \mathrm{~V}$. Furthermore, Figure S8 displays CVs of $\mathbf{P}_{\mathbf{2}} \mathbf{W}_{\mathbf{1 8}} \mathbf{C o}_{\mathbf{4}} @$ MOF-545-DC as a function of the scan rate, whereby the linear dependence of the peak current intensity with respect to the scan rate is consistent with a surface-controlled redox process.

For both EP and DC deposition method, the LSVs show similar electrochemical trends going from bare ITO to MOF-545 thin films to $\mathrm{P}_{2} \mathrm{~W}_{18} \mathrm{Co}_{4} @ \mathrm{MOF}-545$ (Figure 2c). On the bare ITO electrode, water oxidation reaction starts at a potential of $1.88 \mathrm{~V}$. For both MOF-545-EP and MOF-545-DC, the MOF coating has an insulator effect which lowers the current density and does not show any catalytic effect. By contrast, thin films of the full POM@MOF composite show a catalytic wave starting at $+1.62 \mathrm{~V}$ for both $\mathbf{P}_{2} \mathbf{W}_{18} \mathbf{C o}_{4} @$ MOF-545-EP and $\mathbf{P}_{2} \mathbf{W}_{18} \mathrm{Co}_{4} @$ MOF-545DC, in agreement with literature ${ }^{6 \mathrm{~b}}$ and LSVs conducted on a 5 $\mathrm{mM} \mathrm{P}_{2} \mathrm{~W}_{18} \mathrm{Co}_{4}$ solution (Figure S9), thus showing an overpotential for OER of $390 \mathrm{mV}$. To confirm the electrocatalytic OER of the thin films, controlled-potential electrolysis (CPE) experiments were conducted at $1.88 \mathrm{~V}$ vs. RHE in a $80 \mathrm{mM}$ borate buffer solution at $\mathrm{pH} 8$ (Figure 2d). A stable current density was obtained for $2 \mathrm{~h}$ and reproduced after 2 more cycles (same charge passed, see experimental section for details). Blank experiments conducted on either bare ITO electrode or MOF-545 thin films (Figure S10) led to negligible current intensities when compared to those of POM@MOF thin films. The higher current densities observed for $\mathbf{P}_{\mathbf{2}} \mathbf{W}_{\mathbf{1 8}} \mathbf{C o}_{\mathbf{4}} @$ MOF-545-EP $\left(\sim 350 \mu \mathrm{A} \mathrm{cm}{ }^{-2}\right)$ with respect to $\mathbf{P}_{\mathbf{2}} \mathbf{W}_{\mathbf{1 8}} \mathbf{C o}_{\mathbf{4}} @$ MOF-545-DC $\left.(\sim 200 \mu \mathrm{A} \mathrm{cm})^{-2}\right)$ may be explained by the larger quantities of POM@MOF catalyst deposited on EP films when compared to DC ones (one order of magnitude difference). The first evidence for the production of $\mathrm{O}_{2}$ is the formation of bubbles at the electrode surface triggered by the application of the potential. $\mathrm{O}_{2}$ production was measured over the experiments by gas chromatography (Figures $3 \mathrm{a}$ and S11) and was shown to occur linearly over time, consistent with the stable current observed during catalysis. Faradic yields calculated after 2 $\mathrm{h}$ of reaction are close to $100 \%$ for both $\mathbf{P}_{\mathbf{2}} \mathbf{W}_{\mathbf{1 8}} \mathbf{C o}_{\mathbf{4}} @ \mathbf{M O F - 5 4 5 -}$ EP and $\mathbf{P}_{2} \mathbf{W}_{18} \mathbf{C o}_{4} @$ MOF-545-DC. The comparison of electrocatalytic performances of $\mathbf{P}_{2} \mathbf{W}_{18} \mathrm{Co}_{4} @$ MOF-545-DC and $\mathbf{P}_{2} \mathbf{W}_{18} \mathbf{C o}_{4} @$ MOF-545-EP points toward the better activity of DC thin films: turn over numbers (TONs) and turn over frequencies
(TOFs) calculated over $2 \mathrm{~h}$ amount respectively to 527 and $7310^{-3}$ $\mathrm{s}^{-1}$ for $\mathbf{P}_{2} \mathbf{W}_{18} \mathbf{C o}_{\mathbf{4}} @$ MOF-545-EP and 2250 and $31010^{-3} \mathrm{~s}^{-1}$ for $\mathbf{P}_{2} \mathbf{W}_{18} \mathbf{C o}_{4} @$ MOF-545-DC. The remarkably higher performances of $\mathbf{P}_{2} \mathbf{W}_{18} \mathbf{C o}_{\mathbf{4}} @$ MOF-545-DC with respect to $\mathbf{P}_{\mathbf{2}} \mathbf{W}_{18} \mathbf{C o}_{\mathbf{4}} @ \mathbf{M O F}$ 545-EP may be attributed to the larger thickness of EP films $(\sim 20$ $\mu \mathrm{m}$ ) when compared to that of DC films (crystallites size of $\sim 1$ $\mu \mathrm{m})$. Consequently an important proportion of POM@MOF crystallites on top of the film, i.e. far from the conductive ITO support, may not participate to the electrocatalysis as part of an insulating layer of materials in $\mathbf{P}_{\mathbf{2}} \mathbf{W}_{\mathbf{1 8}} \mathrm{Co}_{\mathbf{4}} @ \mathbf{M O F - 5 4 5 - E P}$. For $\mathbf{P}_{2} \mathbf{W}_{18} \mathrm{Co}_{4} @$ MOF-545-DC a higher amount of active sites of the catalytic POM are available owed to a higher dispersion of the sample.

As a reference, CPE conducted on MOF-545-EP and MOF-545DC soaked into a $5 \mu \mathrm{M} \mathrm{Co}\left(\mathrm{NO}_{3}\right)_{2}$ solution led to current densities of only $50 \mu \mathrm{A} \mathrm{cm}^{-2}$ (Figure S10). The current densities were 4 to 7 (DC and EP, respectively) times lower than the POM@MOF thin films, although the total amount of cobalt ions in solution exceeded that in the POM@MOF (75 nmol vs. 23 nmol in EP films). This hints that free cobalt ions are less catalytically active into these conditions than the immobilized $\mathrm{P}_{2} \mathrm{~W}_{18} \mathrm{Co}_{4} \mathrm{POM}$. This also confirms that the observed catalytic activity may not be attributed to leaching and to degradation of the POM into free cobalt ions in solution.

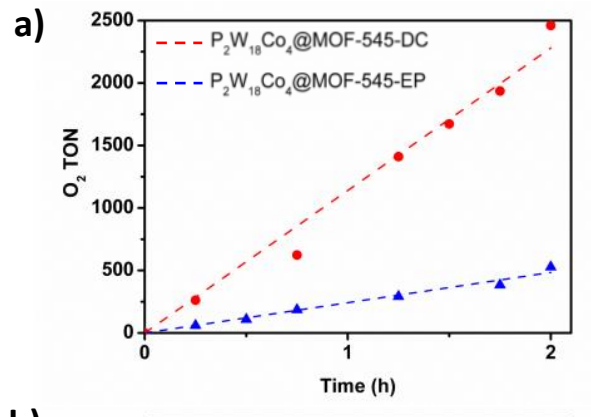

b)

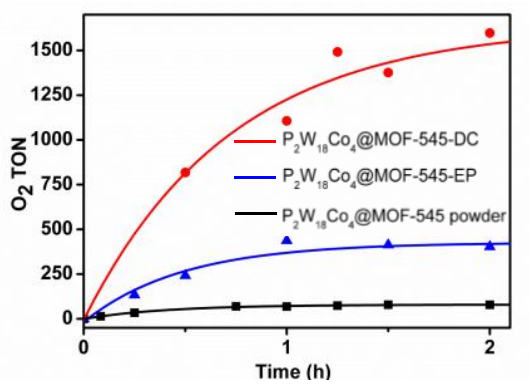

Figure 3. Catalytic activities. (a) $\mathrm{O}_{2}$ TON over time during CPE at $1.85 \mathrm{~V}$ vs. RHE in $80 \mathrm{mM} \mathrm{B}(\mathrm{OH})_{3} \mathrm{pH} 8$ buffer; (b) $\mathrm{O}_{2}$ TON during illumination $\left(5 \mathrm{mM} \mathrm{Na} 2 \mathrm{~S}_{2} \mathrm{O}_{8}\right.$ in $2 \mathrm{~mL}$ of $80 \mathrm{mM}$ borate buffer solution, pH 8, $\lambda>420 \mathrm{~nm}, 280 \mathrm{~W}$ ) for $\mathbf{P}_{\mathbf{2}} \mathbf{W}_{\mathbf{1 8}} \mathbf{C o}_{\mathbf{4}} @ \mathbf{M O F}$ 545-EP (triangles), $\mathbf{P}_{2} \mathbf{W}_{18} \mathrm{Co4} @ \mathrm{MOF}-545-\mathrm{DC}$ (circles) and 0.5 $\mathrm{mg} \mathrm{P}_{2} \mathrm{~W}_{18} \mathrm{Co}_{4} @ \mathrm{MOF}-545$ powder in suspension (squares).

The photocatalytic OER activity of the two types of thin films were studied under visible light irradiation in $\mathrm{pH} 8$ borate buffer, using sodium persulfate $\left(\mathrm{Na}_{2} \mathrm{~S}_{2} \mathrm{O}_{8}\right)$ as the electron acceptor and the MOF's porphyrin ligand as the photosensitizer. As shown in Figure $3 \mathrm{~b}, \mathrm{O}_{2}$ was formed immediately upon exposure to light and increased linearly with time

For $\mathbf{P}_{2} \mathbf{W}_{18} \mathbf{C o}_{4} @$ MOF-545-EP a plateau is reached after $1 \mathrm{~h}$ reaction. The addition of a fresh solution of $\mathrm{Na}_{2} \mathrm{~S}_{2} \mathrm{O}_{8}$ resulted in a restart of $\mathrm{O}_{2}$ production with the same initial TOF (Figure S12). As evidenced previously, ${ }^{38}$ these results show that the system's limitation originates from the depletion of the electron acceptor and prove the stability of the catalytic material. For $\mathbf{P}_{2} \mathbf{W}_{18} \mathrm{Co}_{4} @$ MOF-545-DC, oxygen production slows down but 
still occurs within the $2 \mathrm{~h}$ of the experiment. As control experiments we found that POM@MOF thin films did not show any significant catalytic activity either in the absence of light (Table S2, entries 1-2) or of sacrificial electron acceptor (Table S2, entries 3-4). Similarly the absence of the POM catalyst in MOF545-DC or MOF-545-EP did not allow any significant $\mathrm{O}_{2}$ production (Table S2, entries 5-6). Finally, the activity of MOF-545DC or MOF-545-EP soaked in $5 \mu \mathrm{M} \mathrm{Co}{ }^{\mathrm{II}}$ solution (Table S2, entries 7-8) is far lower than that of the corresponding $\mathrm{P}_{2} \mathrm{~W}_{18} \mathrm{Co}_{4} @$ MOF-545 films. This indicates that free Co ${ }^{\mathrm{II}}$ ions are much less active than the immobilized $\mathrm{P}_{2} \mathrm{~W}_{18} \mathrm{Co}_{4} \mathrm{POM}$.

The two types of thin films exhibit significantly different photocatalytic activities during OER, pointing towards a much higher performance of DC-type thin films. For $\mathbf{P}_{\mathbf{2}} \mathbf{W}_{\mathbf{1 8}} \mathbf{C o}_{\mathbf{4}} @$ MOF-545EP, the TON after $2 \mathrm{~h}$ amounts to 403 and the TOF over the first $30 \mathrm{~min}$ to $13410^{-3} \mathrm{~s}^{-1}$. The corresponding values for $\mathbf{P}_{\mathbf{2}} \mathbf{W}_{18} \mathbf{C o}_{\mathbf{4}} @$ MOF-545-DC are much higher and amount to 1600 (TON) and $46710^{-3} \mathrm{~s}^{-1}$ (TOF). Here, we interpret such differences as a result of the efficient illumination of the POM@MOF photosystem in DC thin films whereby all particles deposited on ITO are exposed to light, while in the thicker (multiple-layered) EP films only the sub-layer of POM@MOF particles indeed exposed to light is functional. Remarkably, both types of films exhibit higher photocatalytic activities than $\mathrm{P}_{2} \mathrm{~W}_{18} \mathrm{Co}_{4} @ \mathrm{MOF}-545$ illuminated in suspension (Figure $3 \mathrm{~b}$ ). This may be again explained not only by the lower quantities of catalyst deposited on films with respect to that in suspension - which tends to increase the calculated TON - but also by a less efficient exposure of crystallites to light when in suspension (random orientation of crystallites, light diffusion by the suspension...). A schematic illustration of such differences between the suspensions, DC and EP films upon light illumination is proposed in Figure 4.

When comparing to existing related published photosystems, the catalytic performances of the $\mathrm{P}_{2} \mathrm{~W}_{18} \mathrm{Co}_{4} @ \mathrm{MOF}-545$ films outperform those reported for homogeneous $\mathrm{P}_{2} \mathrm{~W}_{18} \mathrm{Co}_{4}$-based photosystems (TON of 75). ${ }^{58}$ They are also much higher than those reported for suspensions of other composites $\mathrm{P}_{2} \mathrm{~W}_{18} \mathrm{Co}_{4} @ \mathrm{MIL}-101(\mathrm{Cr})$ (estimated TON of 13) ${ }^{19}$ and $\mathrm{P}_{2} \mathrm{~W}_{18} \mathrm{Co}_{4} @$ MIL-100(Fe) (estimated TON of 16$)^{20}$ as well as those of POM-free MIL-101(Fe) MOFs (TON of 27) ${ }^{28}$ It is worth highlighting here that the use of the external $\left[\mathrm{Ru}(\mathrm{bpy})_{3}\right]^{2+}$ photosensitizer is avoided in our POM@MOF, in contrast with the systems cited above.

In order to investigate the stability of the immobilized $\mathrm{P}_{2} \mathrm{~W}_{18} \mathrm{Co}_{4}$ POM in the POM@MOF thin films during electrocatalysis or photocatalysis, various characterizations were made on both types of thin films.

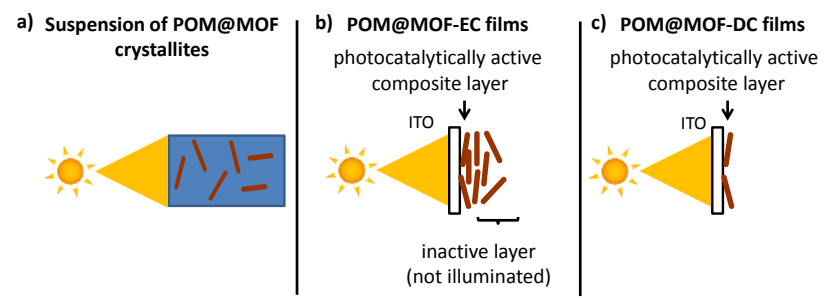

Figure 4. Schematic representation of $\mathrm{P}_{2} \mathrm{~W}_{18} \mathrm{Co}_{4} @ \mathrm{MOF}-545$ photosystem under various setups upon light illumination: a) in suspension; light capture by the crystallites is not optimal (random orientation of crystallites, light diffusion); b) as a thick layer on ITO obtained using electrophoresis (EP); the absorption of light is limited to the fraction of the crystallites in contact with ITO; c) deposited on ITO by drop casting; DC allows depositing small amounts of POM@MOF dispersed on ITO so that all crystallites may be illuminated.

First, DLS measurements were done on both the electrolyte solutions after $\mathrm{CPE}$ and the photocatalytic reaction solution. They showed no particles of size lower than $100 \mathrm{~nm}$, allowing us to exclude the formation of cobalt oxide nanoparticles during the reaction. ${ }^{57}$ These results confirm the absence of leaching of the immobilized $\mathrm{P}_{2} \mathrm{~W}_{18} \mathrm{Co}_{4} \mathrm{POM}$ which is indeed responsible for the observed catalytic properties of the $\mathbf{P}_{2} \mathbf{W}_{18} \mathbf{C o}_{\mathbf{4}} @$ MOF-545 composite. Second, CVs were measured on $\mathbf{P}_{2} \mathbf{W}_{18} \mathbf{C o}_{4} @$ MOF-545EP and $\mathbf{P}_{\mathbf{2}} \mathrm{W}_{18} \mathrm{Co}_{\mathbf{4}} @$ MOF-545-DC after CPE or photocatalysis, and compared to the original ones, showing the persistence of the reversible wave at $1.35 \mathrm{~V}$ vs RHE in all cases (Figure S13). Finally, EXAFS-XANES spectra collected at the Co K-edge energy for $\mathbf{P}_{2} \mathbf{W}_{18} \mathbf{C o}_{4} @$ MOF-545-DC (Figures 5 and S14) and $\mathbf{P}_{2} \mathbf{W}_{18} \mathrm{Co}_{4} @$ MOF-545-EP (Figure S15) after 2h photocatalytic or electrocatalytic experiments showed only a slight shift of the main edge position towards higher energies $(1 \mathrm{eV})$ with respect to the initial material. Given that the pre-edge region does not present any change in intensity or any new peak (Figure 5a), we exclude a net change in the Co oxidation state. We rather attribute this shift to changes in the Co local environment and exclude any drastic modification in its structure. This is furthermore assessed by the similarities between the FT-EXAFS before/after catalysis (Figure $5 b)$ indicating that the POM's integrity is maintained. Also, Raman spectroscopy performed on $\mathbf{P}_{2} \mathbf{W}_{18} \mathbf{C o}_{4} @$ MOF-545-EP shows that the MOF vibrational spectrum is marginally impacted by the POM guest (Figure S16) and remains unchanged after photocatalysis (Figure S17), thus corroborating the integrity of the MOF host upon OER. Finally, SEM images of the electrodes' surface after electro- or photocatalysis showed no difference with the surfaces before catalysis (Figures S18 and S19). All the above characterizations yield converging conclusions toward the POM@MOF photosystem stability in thin films upon OER catalysis.
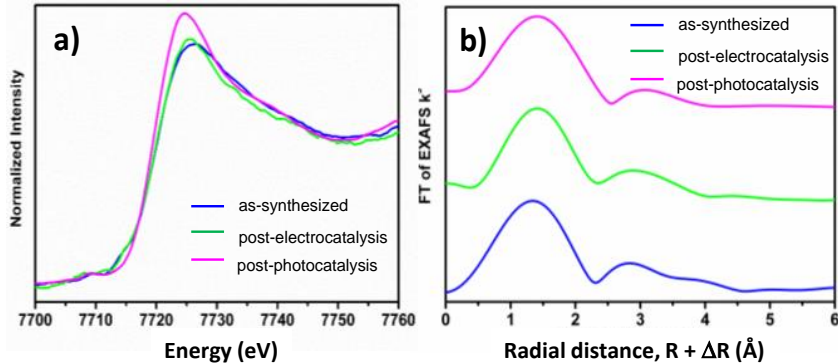

Figure 5. Co K-edge XANES (a) and FT-EXAFS (b) spectra collected at $77 \mathrm{~K}$ of $\mathbf{P}_{\mathbf{2}} \mathbf{W}_{18} \mathbf{C o}_{\mathbf{4}} @$ MOF-545-DC as-synthesized, after electrocatalysis and after photocatalysis.
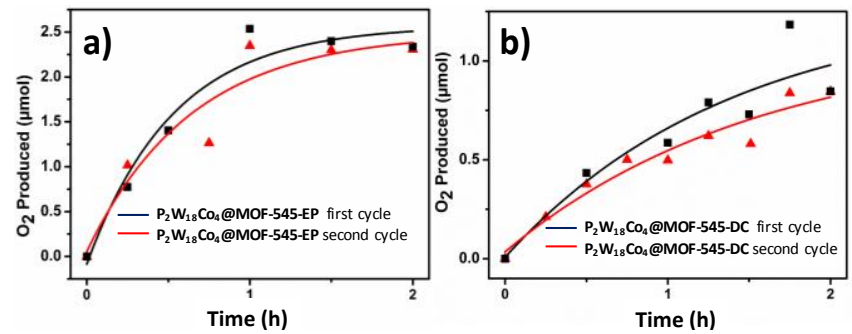

Figure 6. Recyclability of POM@MOF thin films for photocatalytic OER. Kinetics of visible-light-driven $\mathrm{O}_{2}$ production $(5 \mathrm{mM}$ $\mathrm{Na}_{2} \mathrm{~S}_{2} \mathrm{O}_{8}$ in $2 \mathrm{~mL}$ of $80 \mathrm{mM}$ borate buffer solution, $\mathrm{pH} 8, \lambda>420$ $\mathrm{nm}, \quad 280 \mathrm{~W})$ for $\mathbf{P}_{\mathbf{2}} \mathbf{W}_{18} \mathbf{C o}_{\mathbf{4}} @$ MOF-545-EP (a) and $\mathbf{P}_{2} \mathbf{W}_{18}$ Co4@MOF-545-DC (b) for the first cycle (squares) and after renewing the catalytic solution on the same electrode (triangles).

Recyclability was further investigated in photocatalysis. A significant advantage of thin films is the convenient and easy recollection for additional runs. Figure 6 shows that the POM@MOF may 
be reused in another photocatalytic run, with only a small loss in activity (5\% for $\mathbf{P}_{2} \mathbf{W}_{18} \mathbf{C o}_{\mathbf{4}} @ \mathbf{M O F - 5 4 5 - E P}$ and $16 \%$ for $\mathrm{P}_{2} \mathrm{~W}_{18} \mathrm{Co}_{4} @$ MOF-545-DC).

\section{CONCLUSION}

In this work, we have reported the optimization of the catalytic performances of a thin film POM@MOF photosystem for OER, comparing two different techniques of deposition on ITO (dropcasting and electrophoresis). With the long-term goal to develop robust and recyclable heterogeneous noble metal-free photosystems in the field of energy, the present work shows that POM@MOF composites deposited into thin films offer an outstanding benefice in terms of photocatalytic efficiency while allowing their integration into easy-to-use devices. Indeed, the TONs for the photocatalytic $\mathrm{O}_{2}$ production obtained with the $\mathrm{P}_{2} \mathrm{~W}_{18} \mathrm{Co}_{4} @ \mathrm{MOF}-545$ composite are greatly enhanced using thin films when compared to those obtained with the POM@MOF bulk composite in suspension, with estimated TONs of 1600 (DC) and 403 (EP) vs $70 .^{38}$ The relative performances of thin films and suspension (DC $>\mathrm{EP}>$ suspension) may be rationalized by the optimal illumination of the POM@MOF crystallites in DC-type thin films.

Importantly, state of the art techniques provide for the first time evidence for the integrity of the POM catalyst in POM@MOF thin films after electrocatalysis and photocatalysis. Overall, the above results highlight the performances of porphyrin-based MOFs as light-sensitive hosts for the heterogenization of molecular catalysts when coupled with their shaping into thin films for developing heterogeneous photosystems performing key reactions of interest. It is hoped that this work will also promote ongoing interest in the field towards the in-depth characterization of catalysts, which is essential for rationally designing efficient and selective catalysts for OER.

\section{EXPERIMENTAL SECTION}

Materials. $\quad \mathrm{Na}_{10}\left[\left(\mathrm{PW}_{9} \mathrm{O}_{34}\right)_{2} \mathrm{Co}_{4}\left(\mathrm{H}_{2} \mathrm{O}\right)_{2}\right] \quad\left(\mathbf{P}_{\mathbf{2}} \mathbf{W}_{\mathbf{1 8}} \mathbf{C o}_{4}\right)^{59,60}$ tetrakis(4-carboxyphenyl)porphyrin (TCPP-H $\left.\mathbf{H}_{\mathbf{2}}\right){ }^{61} \mathbf{M O F}-\mathbf{5 4 5},{ }^{62,63}$ and $\mathbf{P}_{\mathbf{2}} \mathbf{W}_{\mathbf{1 8}} \mathbf{C o}_{\mathbf{4}} @ \mathbf{M O F - 5 4 5 ^ { 3 8 }}$ were synthesized according to reported procedures. All other reagents were purchased from commercial sources and used as received. ITO-plated glass electrodes were purchased from SOLEMS and cut to reach a 6 x $20 \mathrm{~mm}$ size.

Thin films preparation. $\mathbf{P}_{2} \mathrm{~W}_{18} \mathrm{Co}_{\mathbf{4}} @ \mathrm{MOF}-545-\mathrm{EP}$ was prepared in two steps to avoid exposing the POM to high voltage. To form MOF-545-EP, two ITO electrodes were immersed $3 \mathrm{~mm}$ apart in a colloidal suspension containing $1 \mathrm{mg}$ of MOF-545 in 4 $\mathrm{mL}$ of toluene. A $45 \mathrm{~V}$ cell voltage was then applied between the two electrodes for $30 \mathrm{~min}$, three times consecutively and with no agitation, the MOF suspension being renewed between each cycle. $\mathbf{P}_{\mathbf{2}} \mathbf{W}_{18} \mathbf{C o}_{\mathbf{4}} @ \mathbf{M O F - 5 4 5 - E P}$ was then obtained by immersing the MOF-545-EP electrodes in a $5 \mathrm{mM}$ solution of $\mathbf{P}_{\mathbf{2}} \mathbf{W}_{\mathbf{1 8}} \mathbf{C o}_{\mathbf{4}}$ in a $80 \mathrm{mM} \mathrm{B}(\mathrm{OH})_{3} \mathrm{pH} 8$ buffer solution for 5 hours. The EP thin films were carefully washed with water to allow the release of POMs adsorbed at the surface of MOF particles. $\mathbf{P}_{2} \mathbf{W}_{18} \mathrm{Co}_{4} @$ MOF-545-DC was drop casted $(10 \mu \mathrm{L})$ from a suspension of $1 \mathrm{mg}$ of $\mathbf{P}_{\mathbf{2}} \mathbf{W}_{18} \mathbf{C o}_{\mathbf{4}} @$ MOF-545 in $1 \mathrm{~mL}$ of ethanol on an ITO electrode of area $36 \mathrm{~mm}^{2}$ and let drying at room temperature for $10 \mathrm{~min}$. For $\mathbf{P}_{\mathbf{2}} \mathbf{W}_{\mathbf{1 8}} \mathbf{C o}_{\mathbf{4}} @ \mathbf{M O F}-\mathbf{5 4 5}-\mathbf{D C}$, the material mass was calculated at $0.01 \mathrm{mg}$ according to the concentration and volume of the deposited drop. For $\mathbf{P}_{\mathbf{2}} \mathbf{W}_{\mathbf{1 8}} \mathbf{C o}_{\mathbf{4}} @$ MOF-545$\mathbf{E P}$, the mass of deposited material was measured by weighting the material over 20 electrodes prepared in identical conditions, leading to an averaged deposited MOF amount of $0.11 \mathrm{mg}$. Using the chemical formula $\left(\left[\mathrm{Zr}_{6} \mathrm{O}_{18} \mathrm{H}_{18}\right]_{3}\left[\mathrm{C}_{48} \mathrm{H}_{26} \mathrm{O}_{8} \mathrm{~N}_{4}\right]_{6}\right.$ $\left.\left[\mathrm{P}_{2} \mathrm{~W}_{18} \mathrm{O}_{70} \mathrm{Co}_{4} \mathrm{H}_{4}\right]_{0.6} \cdot 78 \mathrm{H}_{2} \mathrm{O}\right)$ determined for the $\mathrm{P}_{2} \mathrm{~W}_{18} \mathrm{Co}_{4} @$ MOF-545 powder, ${ }^{38} \quad \mathbf{P}_{2} \mathbf{W}_{18} \mathbf{C o}_{4} @$ MOF-545-DC contains $0.53 \mathrm{nmol}$ and $\mathbf{P}_{\mathbf{2}} \mathbf{W}_{\mathbf{1 8}} \mathbf{C o}_{\mathbf{4}} @$ MOF-545-EP $5.8 \mathrm{nmol}$ of $\mathrm{P}_{2} \mathrm{~W}_{18} \mathrm{Co}_{4}$, equivalent to $1.5 \mathrm{nmol} \mathrm{cm}$ and $16 \mathrm{nmol} \mathrm{cm}$ of $\mathrm{POM}$ respectively.

Physical methods. Infrared (IR) spectra were recorded on a Nicolet 30 ATR 6700 FT spectrometer. Powder X-ray diffraction (PXRD) data were obtained on a Bruker D5000 diffractometer using $\mathrm{Cu}$ radiation (1.54059 ̊). Energy dispersive spectroscopy (EDS) measurements were performed on a JEOL JSM 5800LV apparatus. X-ray absorption spectra were recorded on the SAMBA beamline of SOLEIL at a ring energy of $2.75 \mathrm{GeV}$ and a current of $500 \mathrm{~mA}$. The incident energy was selected using a $\mathrm{Si}(222)$ double-crystal monochromator and calibrated to the first inflection point of a Co foil $(\mathrm{E}=7709 \mathrm{eV})$. Measurements were performed in fluorescence mode using a Bruker fluorescence detector. The optical properties of $\mathrm{P}_{2} \mathrm{~W}_{8} \mathrm{Co}_{4} @ \mathrm{MOF}-545$ and MOF-545 may be found in reference 38. Raman spectra were measured on a home-made Raman spectrometer at $532 \mathrm{~nm}$, the spectrum being acquired with a fiber coupled spectrometer coupled to a CCD camera (IsoPlane SCT 320 mounted with a PIXIS, using a 1800 lines grating; Princeton Inst.). An interferential filter was used to cut the elastic scattering. The spectral resolution was set to $6 \mathrm{~cm}^{-1}$. The laser power was adjusted to about 1-2 $\mathrm{mW}$ on the sample to avoid laser damage. Solid-state ${ }^{31} \mathrm{P}$ MAS NMR was recorded on a Bruker Avance $500 \mathrm{MHz}$ spectrometer $\left(B_{0}=11.7\right.$ $\mathrm{T})$. The sample was packed in a $2.5 \mathrm{~mm}$ zirconia rotor and spun at $30 \mathrm{kHz}$ MAS rate. The spectrum was recorded using rotorsynchronized Hahn-echo sequence $90^{\circ}-\tau-180^{\circ}-\tau$. The $90^{\circ}$ pulse length was $2.3 \mu \mathrm{s}$, the $\tau$ delay $33 \mu \mathrm{s}$, and the recycle delay $0.1 \mathrm{~s}$. The spectrum was an accumulation of ca. 105000 transients. Solution ${ }^{31} \mathrm{P}$ NMR spectra were recorded on a Bruker Avance 400 apparatus at $162.3 \mathrm{MHz}$. Chemical shifts were referenced to $85 \%$ $\mathrm{H}_{3} \mathrm{PO}_{4}$.

Photocatalytic activity measurements. Similar conditions than those used for studying the OER catalytic performances of suspensions of $\mathrm{P}_{2} \mathrm{~W}_{18} \mathrm{Co}_{4} @ \mathrm{MOF}-545$ were used to ensure the MOF and POM's stability. ${ }^{38}$ Electrodes were fixed to a wall of a quartz cuvette with a volume of $4.2 \mathrm{~mL}$. The cuvette was then filled with $2 \mathrm{~mL}$ of a $5 \mathrm{mM} \mathrm{Na} 2 \mathrm{~S}_{2} \mathrm{O}_{8}$ solution in $80 \mathrm{mM} \mathrm{B}(\mathrm{OH})_{3} \mathrm{pH} 8$ buffer, sealed, thoroughly degassed using nitrogen and finally placed in a temperature controlled block at $20^{\circ} \mathrm{C}$. The thin films were irradiated with a $280 \mathrm{~W}$ Xenon light source equipped with a $420 \mathrm{~nm}$ filter and a water infrared filter. Oxygen produced was measured by analyzing $50 \mu \mathrm{L}$ aliquots from the cuvette's headspace by gas chromatography on a Shimadzu GC-2014 equipped with a thermal conductivity detector and a Quadrex column. $\mathrm{O}_{2}$ quantification was achieved accordingly to the corresponding calibration curves.

Electrocatalytic characterization and activity measurements. Electrochemical studies were conducted in similar conditions than the photocatalytic experiments using an SP 300 potentiostat (BioLogic Science Instruments SAS). All the electrochemical experiments were performed at room temperature in a $15 \mathrm{~mL}, 80 \mathrm{mM}$ $\mathrm{B}(\mathrm{OH})_{3} \mathrm{pH} 8$ buffer using ultrapure water produced by a Millipore system $\left(18.2 \mathrm{M} \Omega\right.$ at $\left.25^{\circ} \mathrm{C}\right)$ and $1 \mathrm{M} \mathrm{NaOH}$ to adjust $\mathrm{pH}$. Solutions were deaerated using nitrogen gas. CVs and controlled potential electrolysis were carried out at room temperature in a gas-tight two-compartment electrochemical cell. Cathodic and anodic compartments were separated via a glass-frit of fine porosity. The counter electrode was a platinum wire, the reference 
electrode was a saturated $\mathrm{Ag} / \mathrm{AgCl} / \mathrm{KCl}$ electrode separated from the electrolyte by a salt bridge and the working electrode was the relevant ITO-coated glass electrode. The electrochemical surface area was underestimated by measuring the geometrical area of the electrode. Electric contact between the ITO surface and the potentiostat was made through copper tape. Production of oxygen in the anodic headspace gas was measured using the same methods as for photocatalytic activity measurements. Recyclability experiments (3 cycles) were performed obtaining the same current densities and charge passed for $2 \mathrm{~h}$. The electrode was removed, rinsed with ethanol and immersed in a new deaerated buffer solution. All TONs and TOFs were estimated by normalizing the production of $\mathrm{O}_{2}$ with the number of nmol of POM.

XAFS analyses. X-Ray Absorption Fine Structure (XAFS) spectroscopy analyses were done at SAMBA beamline, Synchrotron SOLEIL, France. The storage ring was operated with a $2.75 \mathrm{GeV}$ electron energy ring, $500 \mathrm{~mA}$ current, and multi-bunch mode. Thin films or powders pressed into pellets of $\mathrm{P}_{2} \mathrm{~W}_{18} \mathrm{Co}_{4}$, $\mathrm{P}_{2} \mathrm{~W}_{18} \mathrm{Co}_{4} @$ MOF-545, $\quad \mathrm{P}_{2} \mathrm{~W}_{18} \mathrm{Co}_{4} @$ MOF-545-DC, and $\mathrm{P}_{2} \mathrm{~W}_{18} \mathrm{Co}_{4} @$ MOF-545-EP were analyzed at $77 \mathrm{~K}$ using a $\mathrm{N}_{2}$ cryostat. X-Ray Absorption Near Edge Structure (XANES) and Extended X-Ray Absorption Fine Structure (EXAFS) spectroscopy spectra were collected at the Co K edge $(7709 \mathrm{eV})$ between 7500 and $8335 \mathrm{eV}$. Acquisitions were done in fluorescence mode using a Ge multi-pixel fluorescence detector (Canberra). All spectra were processed using Athena featured in Demeter Software Package. ${ }^{64}$

\section{ASSOCIATED CONTENT}

Supporting Information. Experimental details, PXRD, SEM, CVs, LSVs, CPEs, XANES-EXAFS spectra, NMR and Raman spectra. This material is available free of charge via the Internet at http://pubs.acs.org.

\section{AUTHOR INFORMATION}

\section{Corresponding Author}

* E-mail: caroline.mellot-draznieks@ college-de-france.fr

* E-mail: anne.dolbecq@uvsq.fr

* E-mail: maria.gomez @ college-de-france.fr

\section{Notes}

The authors declare no competing financial interest.

\section{ACKNOWLEDGMENT}

This work was supported by CNRS, UVSQ, the Ministère de l'Enseignement supérieur, de la Recherche et de l'Innovation, the French National Research Agency (ANR) as part of the "Investissements d'Avenir" program n ${ }^{\circ}$ ANR-11-IDEX-0003-02 and CHARMMMAT ANR-11-LABX-0039 and PEPS Energie 2018 SOL2CAT program. We acknowledge assistance from SOLEIL beamline staff. AD thanks Bruno Berini for profilometry measurements. Youven Benseghir, Mathis Duguet and Alex Lemarchand are gratefully acknowledged for their participation in EXAFS and XANES experiments.

\section{REFERENCES}

(1) Farrusseng, D.; Aguado, S.; Pinel, C. Metal-Organic Frameworks: Opportunities for Catalysis. Angew. Chem. Int. Ed. 2009, 48, 75027513.

(2) Cohen, S. M. Postsynthetic Methods for the Functionalization of Metal-Organic Frameworks. Chem. Rev. 2012, 112, 970-1000.

(3) Yang, D.; Gates B. C., Catalysis by Metal Organic Frameworks: Perspective and Suggestions for Future Research. ACS Catal. 2019, 9, 1779-1798.
(4) Zhang, T.; Lin, W. Metal-organic Frameworks for Artificial Photosynthesis and Photocatalysis. Chem. Soc. Rev. 2014, 43, 5982-5993. (5) Wang, S. B.; Wang, X. C. Multifunctional Metal-Organic Frameworks for Photocatalysis. Small 2015, 11, 3097-3112.

(6) Dhakshinamoorthy, A.; Asiri, A. M.; Garcia, H. Metal-Organic Framework (MOF) Compounds: Photocatalysts for Redox Reactions and Solar Fuel Production. Angew. Chem. Int. Ed. 2016, 55, 54145445 .

(7) Solomon, M. B.; Churcha, T. L.; D'Alessandro, D. M. Perspectives on Metal-organic Frameworks with Intrinsic Electrocatalytic Activity. CrystEngComm. 2017, 19, 4049-4065.

(8) Liao, P.-Q.; Shen, J.-Q.; Zhang, J.-P. Metal-Organic Frameworks for Electrocatalysis and Photocatalysis. Coord. Chem. Rev. 2018, 373, 22-48.

(9) Majewski, M. B.; Peters, A. W.; Wasielewski, M. R.; Hupp, J. T.; Farha, O. K. Metal-Organic Frameworks as Platform Materials for Solar Fuels Catalysis. ACS Energy Lett. 2018, 3, 598-611.

(10) Liao, P.-Q.; Shen, J.-Q.; Zhang. J.-P. Metal-Organic Frameworks for Electrocatalysis, Coord. Chem. Rev. 2018, 373, 22-48.

(11) Meyer, K.; Ranocchiari, M.; van Bokhoven, J. A. Metal Organic Frameworks for Photo-Catalytic Water Splitting. Energy Environ. Sci. 2015, 8, 1923-1937.

(12) Downes, C.A.; Marinescu, S. C. Electrocatalytic Metal-Organic Frameworks for Energy Applications. ChemSusChem. 2017, 10, 4374-4392.

(13) Zhang, L.; Cui, P.; Yang, H.; Chen, J.; Xiao, F.; Guo, Y.; Liu, Y.; Zhang, W.; Huo, F.; Liu, B. Metal-Organic Frameworks as Promising Photosensitizers for PhotoElectrochemical Water Splitting. Adv. Sci. 2016, 3, 1500243.

(14) Wang, W.; Xu, X.; Zhou, W.; Shao, Z. Recent Progress in Metal-Organic Frameworks for Applications in Electrocatalytic and PhotoCatalytic Water Splitting. Adv. Sci. 2017, 4, 1600371.

(15) Low, J. J. ; Benin, A. I.; Jakubczak, P. ; Abrahamian, J. F. ; Faheem S. A.; Willis, R. R. Virtual High Throughput Screening Confirmed Experimentally: Porous Coordination Polymer Hydration. J. Am. Chem. Soc. 2009, 131, 15834-15842.

(16) Wang, S.; Hou, Y.; Lin, S.; Wang, X. Water Oxidation Electrocatalysis by a Zeolitic Imidazolate Framework. Nanoscale 2014, 6 , 9930-9934.

(17) Flügel, E. A.; Lau, V. W. H.; Schlomberg, H.; Glaum, R.; Lotsch, B. V. Homonuclear Mixed-Valent Cobalt Imidazolate Framework for Oxygen-Evolution Electrocatalysis. Chem.-Eur. J. 2016, 22, 3676-3680.

(18) Mukhopadhyay, S.; Debgupta, J.; Singh, C.; Kar, A.; Da, S. K. A Keggin Polyoxometalate Shows Water Oxidation Activity at Neutral pH: POM@ZIF-8, an Efficient and Robust Electrocatalyst. Angew. Chem. Int. Ed. 2018, 57, 1918-1923.

(19) Han, J.; Wang, D.; Du, Y. H.; Xi, S.; Chen, Z.; Yin, S.; Zhou, T.; Xu, R.. Appl. Catal. A 2016, 521, 83-89.

(20) Ali Shah, W.; Waseem, A.; Nadeem, M. A.; Kögerler, P. Leaching-free Encapsulation of Cobalt-Polyoxotungstates in MIL-100(Fe) for Highly Reproducible Photocatalytic Water Oxidation. Appl. Catal. 2018, 567, 132-138.

(21) Dai, F.; Fan, W.; Bi, J. ; Jiang, P.; Liu, D.; Zhang, X.; Lin, H.; Gong, C.; Wang, R.; Zhang L.; Sun, D. A Lead-porphyrin MetalOrganic Framework: Gas Adsorption Properties and Electrocatalytic Activity for Water Oxidation. Dalton Trans. 2016, 45, 61-65.

(22) Usov, P. M.; Ahrenholtz, S. R.; Maza, W. A.; Stratakes, B.; Epley, C. C.; Kessinger, M. C.; Zhu, J.; Morris, A. J. Cooperative Electrochemical Water Oxidation by $\mathrm{Zr}$ Nodes and $\mathrm{Ni}$-porphyrin Linkers of a PCN-224 MOF Thin Film. J. Mater. Chem. A 2016, 4, 16818-16823.

(23) Usov, P. M.; Huffman, B.; Epley, C. C.; Kessinger, M. C.; Zhu, J.; Maza, W. A.; Morris, A. J. Study of Electrocatalytic Properties of Metal-Organic Framework PCN-223 for the Oxygen Reduction Reaction. ACS Appl. Mater. Interfaces 2017, 9, 33539-33543.

(24) Dong, Y.-J.; Liao, J.-F.; Kong, Z.-C.; Xu, Y.-F. ; Chen, Z.-J.; Chen, H.-Y.; Kuang, D.-B.; Fenske, D.; Su, C.-Y. Conformal Coating of Ultrathin Metal-organic Framework on Semiconductor Electrode for Boosted Photoelectrochemical Water Oxidation. Appl. Catal. B: Env. 2018, 237, 9-17. 
(25) Gong, Y.-N.; Ouyang, T.; He, C.-T.; Lu, T.-B. Photoinduced Water Oxidation by an Organic Ligand Incorporated into the Framework of a Stable Metal-Organic Framework. Chem. Sci. 2016, 7, 1070-1075

(26) Liu, Y.; Zhang, W.; Huo, F.; Liu, B. Metal-Organic Frameworks as Promising Photosensitizers for PhotoElectrochemical Water Splitting. Adv. Sci. 2016, 3, 1500243.

(27) Lionet, Z.; Kamata, Y.; Nishijima, S.; Toyao, T.; Kim, T.-H.; Horiuchi, Y.; Wohn Lee, S. Matsuoka, M. Water Oxidation Reaction Promoted by MIL-101(Fe) Photoanode under Visible Light Irradiation. Res. Chem. Intermed. 2018, 44, 4755-4764.

(28) Che, L.; Xu, Q.; Liang, X.; Wang, J.; Su, X. Iron-Based MetalOrganic Frameworks as Catalysts for Visible Light-Driven Water Oxidation. Small 2016, 12, 1351-1358.

(29) Wang, C.; Xie, Z.; deKrafft, K. E.; Lin, W. Doping MetalOrganic Frameworks for Water Oxidation, Carbon Dioxide Reduction, and Organic Photocatalysis. J. Am. Chem. Soc. 2011, 133, 13445-13454.

(30) Lee, C. Y.; Farha, O. K.; Hong, B. J.; Sarjeant, A. A.; Nguyen, S. T.; Hupp, J. T. Light-Harvesting MOFs: Efficient Strut-to-Strut Energy Transfer in Bodipy and Porphyrin-Based MOFs. J. Am. Chem. Soc. 2011, 133, 15858-15861.

(31) Hendon, C.-H.; Tiana, D.; Fontecave, M.; Sanchez, C.; D'arras, L.; Sassoye, C.; Rozes, L.; Mellot-Draznieks C.; Walsh, A., Engineering the Optical Response of the Titanium-MIL-125 Metal-Organic Framework Through Ligand Functionalization. J. Am. Chem. Soc. 2013, 135, 10942-10945.

(32) Son, H.-J.; Jin, S.; Patwardhan, S.; Wezenberg, S. J.; Jeong, N. C.; So, M.; Wilmer, C. E.; Sarjeant, A. A.; Schatz, G. C.; Snurr, R. Q.; Farha, O. K.; Wiederrecht, G. P.; Hupp, J. T. Light-Harvesting and Ultrafast Energy Migration in Porphyrin-Based Metal-Organic Frameworks. J. Am. Chem. Soc. 2013,135, 862-869.

(33) Amador, R. N.; Carboni, M.; Meyer, D., Photosensitive Titanium and Zirconium Metal Organic Frameworks: Current Research and Future Possibilities. Mater. Lett. 2016, 166, 327-338.

(34) Liang, Z.; Qu, C.; Xia, D.; Zou, R.; Xu, Q., Atomically Dispersed Metal Sites in MOF-Based Materials for Electrocatalytic and Photocatalytic Energy Conversion. Angew. Chem. Int. Ed. 2018, 57, $9604-9633$.

(35) Gu, Z.-Y.; Park, J.; Raiff, A.; Wei, Z.; Zhou, H.-C. MetalOrganic Frameworks as Biomimetic Catalysts. ChemCatChem. 2014, 6, 67-75.

(36) Maina, J. W.; Pozo-Gonzalo, C.; Kong, L.X.; Schutz, J.; Hill, M.; Dumee, L. F. Metal Organic Framework Based Catalysts for $\mathrm{CO}_{2}$ Conversion. Mater. Horizons 2017, 4, 345-361.

(37) Chi , L.; Xu , Q.; Liang, X.; Wang, J.; Su, X. Iron-Based MetalOrganic Frameworks as Catalysts. Small 2016, 12, 1351-1358.

(38) Paille, G.; Gomez-Mingot, M.; Roch-Marchal, C.; LassalleKaiser, B.; Mialane, P.; Fontecave, M.; Mellot-Draznieks, C.; Dolbecq, A. A Fully Noble Metal-Free Photosystem Based on CobaltPolyoxometalates Immobilized in a Porphyrinic Metal-Organic Framework for Water Oxidation. J. Am. Chem. Soc. 2018, 140, 3613-3618.

(39) Bétard, A.; Fischer, R. A. Metal Organic Framework Thin Films: From Fundamentals to Applications. Chem. Rev. 2012, 112, 10551083.

(40) Liu, J.; Wöll, C. Surface-supported Metal-organic Framework Thin Films: Fabrication Methods, Applications, and Challenges. Chem. Soc. Rev. 2017, 46, 5730-5770.

(41) Genesio, G.; Maynadié, J.; Carboni, M.; Meyer, D. Recent Status on MOF Thin Films on Transparent Conductive Oxides Substrates (ITO or FTO). New. J. Chem. 2018, 42, 2351-2363.

(42) Al-Kutubi, H.; Gascon, J.; Sudhölter, E. J. R.; Rassaei, L. Electrosynthesis of Metal-Organic Frameworks: Challenges and Opportunities. ChemElectroChem 2015, 2, 462-474.

(43) Zhao, S.; Yun, W.; Dong, J.; He, C.-T.; Yin, H.; An, P.; Zhao, K.; Zhang, X.; Gao, C.; Zhang, L.; Lv, J.; Wang, J.; Zhang, J.; Khattak, A. M.; Khan, N. A.; Wei, Z.; Zhang, J.; Liu, S.; Zhao, H.; Tang, Z. Ultrathin Metal-organic Framework Nanosheets for Electrocatalytic Oxygen Evolution. Nat. Energy 2016, 1, 16184.
(44) So, M. C.; Beyzavi, M. H.; Sawhney, R.; Shekhah, O.; Eddaoudi, M.; Al-Juaid, S. S.; Hupp, J. T.; Farha, O. K. Post-Assembly Transformations of Porphyrin-Containing Metal-Organic Framework (MOF) Films Fabricated Via Automated Layer-by-Layer Coordination. Chem. Commun. 2015, 51, 85-88.

(45) Liu, J. X.; Zhou, W. C.; Liu, J. X.; Howard, I.; Kilibarda, G.; Schlabach, S.; Coupry, D.; Addicoat, M.; Yoneda, S.; Tsutsui, Y.; Sakurai, T.; Seki, S.; Wang, Z. B.; Lindemann, P.; Redel, E.; Heine, T.; Wöll, C. Photoinduced Charge-Carrier Generation in Epitaxial MOF Thin Films: High Efficiency as a Result of an Indirect Electronic Band Gap. Angew. Chem. Int. Ed. 2015, 54, 7441-7445.

(46) Hod, I.; Sampson, M. D.; Deria, P.; Kubiak, C. P.; Farha, O. K.; Hupp, J. T. Fe-Porphyrin-Based Metal Organic Framework Films as High-Surface Concentration, Heterogeneous Catalysts for Electrochemical Reduction of $\mathrm{CO}_{2}$. ACS Catal. 2015, 5, 6302-6309.

(47) Kung, C.-W.; Chang, T.-H.; Chou, L.-Y.; Hupp, J. T.; Farha, O. K.; Ho, K.-C. Porphyrin-Based Metal-organic Framework Thin Films for Electrochemical Nitrite Detection. Electrochem. Comm. 2015, 58, $51-56$.

(48) Kornienko, N.; Zhao, Y.; Kley, C. S.; Zhu, D. Kim, S. Lin, C. J. Chang, O. M. Yaghi, P. Metal-organic frameworks for Electrocatalytic Reduction of Carbon Dioxide. J. Am. Chem. Soc. 2015, 137, 14129-14135.

(49) Wang, Y. X.; Zhao, M. T.; Ping, J. F.; Chen, B.; Cao, X. H.; Huang, Y.; Tan, C. L.; Ma, Q. L.; Wu, S. X.; Yu, Y. F.; Lu, Q. P.; Chen, J. Z.; Zhao, W.; Ying, Y. B.; Zhang, H. Bioinspired Design of Ultrathin 2D Bimetallic Metal-Organic-Framework Nanosheets Used as Biomimetic Enzymes. Adv. Mater. 2016, 28, 4149-4155.

(50) Kung, C.-W.; Chang, T.-H.; Chou, L.-Y.; Hupp, J. T.; Farha, O. K.; Ho, K.-C. Post Metalation of Solvothermally Grown Electroactive Porphyrin Metal-organic Framework Thin Films. Chem. Commun. 2015, 51, 2414-2417.

(51) So, M. C.; Jin, S.; Son, H.-J.; Wiederrecht, G. P.; Farha, O. K.; Hupp, J. T. Layer-by-layer Fabrication of Oriented Porous Thin Films Based on Porphyrin-containing Metal-organic Frameworks. J. Am. Chem. Soc. 2013, 135, 15698-15701.

(52) Wang, L.; Wu, Y.; Cao, R.; Ren, L.; Chen, M.; Feng, X.; Zhou, J.; Wang, B. Fe/Ni Metal-Organic Frameworks and Their BinderFree Thin Films for Efficient Oxygen Evolution with Low Overpotential. ACS Appl. Mater. Interfaces 2016, 8, 16736-16743.

(53) (a) Kung, C.-W.; Chang, T.-H.; Chou, L.-Y.; Hupp, J. T.; Farha, O. K.; Ho, K.-C. Post Metalation of Solvothermally Grown Electroactive Porphyrin Metal-organic Framework Thin Films. Chem. Commun. 2015, 51, 2414-2417.

(54) Maza, W. A.; Ahrenholtz, S. R.; Epley, C. C.; Day, C. S.; Morris, A. J. Solvothermal Growth and Photophysical Characterization of a Ruthenium(II) Tris(2,2'-Bipyridine)-Doped Zirconium UiO-67 MetalOrganic Framework Thin Film. J. Phys. Chem. C 2014, 118, 1420014210.

(55) Salomon, W.; Yazigi, F.; Roch-Marchal, C.; Mialane, P.; Horcajada, P.; Serre, C.; Haouas, M.; Taulelle, F.; Dolbecq, A. Immobilization of Co-Containing Polyoxometalates in MIL-101Cr: Structural Integrity Versus Chemical Transformation. Dalton Trans. 2014, 12698-12705.

(56) Schiwon, R.; Klingan, K.; Dau, H.; Limberg, C. Shining Light on Integrity of a Tetracobalt-Polyoxometalate Water Oxidation Catalyst by X-Ray Spectroscopy Before and After Catalysis. Chem. Commun. 2014, 50, 100-102.

(57) Stracke, J. J.; Finke, R. G. Distinguishing Homogenous From Heterogeneous Water Oxidation Catalysis when Beginning with Polyoxometalates. ACS Catal. 2014, 4, 909-933.

(58) Huang, Z.; Luo, Z.; Geletii, Y. V.; Yin, O.; Wickers, J. W.; Yin, Q.; Wu, D.; Hou, Y.; Ding, Y.; Song, J.; Musaev, D. G.; Hill, C. L.; Lian, T. Efficient Light-Driven Carbon Free Cobalt-based Molecular Catalyst for Water Oxidation. J. Am. Chem. Soc. 2011, 133, 20682071.

(59) Finke, R. G.; Droege, M. W.; Domaille, P. J. Rational Syntheses, Characterization, Two-Dimensional ${ }^{183} \mathrm{~W}$ NMR, and Properties of $\mathrm{P}_{4} \mathrm{~W}_{18} \mathrm{M}_{4}\left(\mathrm{H}_{2} \mathrm{O}\right)_{2} \mathrm{O}_{68}{ }^{10-}$ and $\mathrm{P}_{4} \mathrm{~W}_{30} \mathrm{M}_{4}\left(\mathrm{H}_{2} \mathrm{O}\right)_{2} \mathrm{O}_{112}{ }^{16-}(\mathrm{M}=\mathrm{Co}, \mathrm{Cu}, \mathrm{Zn})$. Inorg. Chem. 1987, 9, 3886-3896. 
(60) Weakley, T. J. R.; Evans Jun., H. T.; Showell, J. S.; Tourné, G. F.; Tourné, C. M. 18-Tungstotetracobalto(II)Diphosphate and Related Anions: A Novel Structural Class of Heteropolyanions. J. Chem. Soc., Chem. Commun 1973, 4, 139-140.

(61) Feng, D.; Gu, Z. Y.; Li, J. R.; Jiang, H. L.; Wei, Z.; Zhou, H. C. Zirconium-Metalloporphyrin PCN-222: Mesoporous Metal-Organic Frameworks With Ultrahigh Stability as Biomimetic Catalysts. Angew. Chem. Int. Ed. 2012, 51, 10307-10310.

(62) Morris; W; Volosskiy, B.; Demir, S.; Gándara, F.; McGrier, P. L.; Furukawa, H.; Cascio, D.; Stoddart, J. F.; Yaghi, O. M. Synthesis,
Structure, and Metalation of Two New Highly Porous Zirconium Metal-Organic Frameworks. Inorg Chem.. 2012, 51, 6443-6445.

(63) Feng, D.; Gu, Z. Y.; Li, J. R.; Jiang, H. L., Wei, Z.; Zhou, H. C. Zirconium-Metalloporphyrin PCN-222: Mesoporous Metal-Organic Frameworks With Ultrahigh Stability as Biomimetic Catalysts. Angew. Chem. Int. Ed. Engl. 2012, 41, 10307-10310.

(64) Ravel, B.; Newville, M. ATHENA, ARTEMIS, HEPHAESTUS: Data Analysis For X-ray Absorption Spectroscopy Using IFEFFIT. $J$. Synch. Rad. 2005, 12, 537-541. 
Table of Contents Graphic

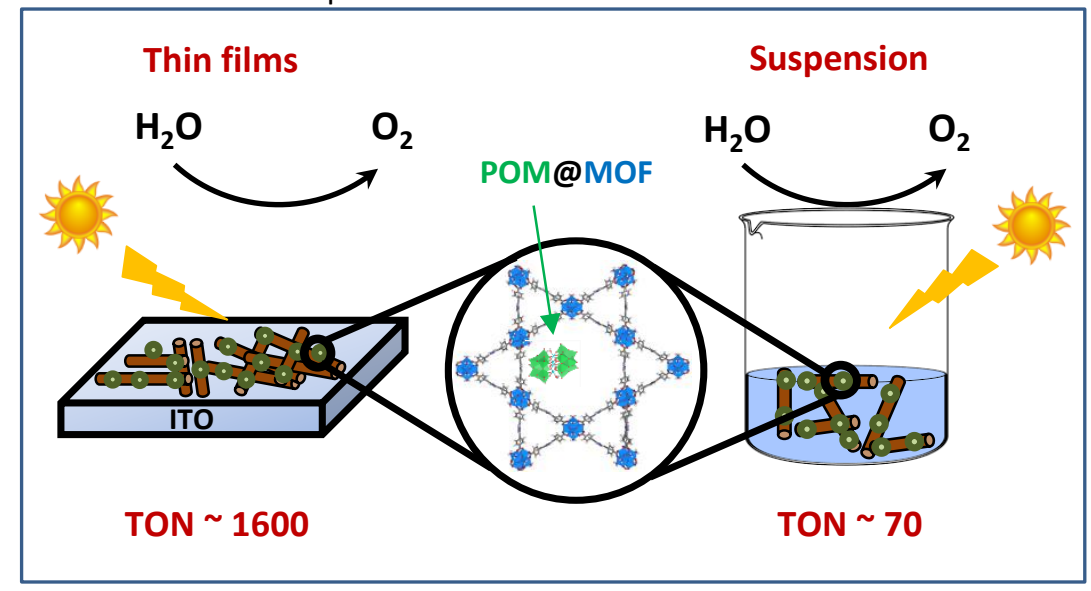

